\title{
Chitinase-like proteins as regulators of innate immunity and tissue repair: helpful lessons for asthma?
}

DOI:

10.1042/BST20170108

\section{Document Version}

Accepted author manuscript

Link to publication record in Manchester Research Explorer

\section{Citation for published version (APA):}

Sutherland, T. (2018). Chitinase-like proteins as regulators of innate immunity and tissue repair: helpful lessons for asthma? Biochemical Society. Transactions, 46(1), 145-151. https://doi.org/10.1042/BST20170108

\section{Published in:}

Biochemical Society. Transactions

\section{Citing this paper}

Please note that where the full-text provided on Manchester Research Explorer is the Author Accepted Manuscript or Proof version this may differ from the final Published version. If citing, it is advised that you check and use the publisher's definitive version.

\section{General rights}

Copyright and moral rights for the publications made accessible in the Research Explorer are retained by the authors and/or other copyright owners and it is a condition of accessing publications that users recognise and abide by the legal requirements associated with these rights.

\section{Takedown policy}

If you believe that this document breaches copyright please refer to the University of Manchester's Takedown Procedures [http://man.ac.uk/04Y6Bo] or contact uml.scholarlycommunications@manchester.ac.uk providing relevant details, so we can investigate your claim.

\section{OPEN ACCESS}


Chitinase-like proteins as regulators of innate immunity and tissue repair: helpful lessons for asthma?

Tara E. Sutherland

Faculty of Biology, Medicine \& Health, Manchester Collaborative Centre for Inflammation Research, Manchester Academic Health Science Centre, University of Manchester, Manchester M13 9NT, UK

tara.sutherland@manchester.ac.uk 


\begin{abstract}
Chitinases and chitinase-like proteins (CLPs) belong to the glycoside hydrolase $18\left(\mathrm{GH}_{1} 8\right)$ family of proteins. Chitinases are expressed in mammals and lower organisms and facilitate chitin degradation, hence act as host-defence enzymes. Gene duplication and loss-of-function mutations of enzymatically active chitinases has resulted in the expression of a diverse range of CLPs across different species. CLPs are genes that are increasingly associated with inflammation and tissue remodelling, not only in mammals but also across distant species. Whilst the focus has remained on understanding the functions and expression patterns of CLPs during disease in humans, studies in mouse and lower organisms have revealed important and overlapping roles of the CLP family during physiology, host-defence and pathology. This review will summarise recent insights into the regulatory functions of CLPs on innate immune pathways and discuss how these effects are not only important for host-defence and tissue injury/repair after pathogen invasion, but also how they have extensive implications for pathological processes involved in diseases such as asthma.
\end{abstract}




\section{Chitinase-like proteins - functions within an ancient protein family}

Glycoside hydrolase family $18\left(\mathrm{GH}_{1} 8\right)$ proteins encompass the enzymatically active chitinases and enzymatically inactive chitinase-like proteins (CLPs). Chitinases hydrolyse glycosidic bonds of chitin, an abundant polysaccharide found as a structural component of the fungal and bacterial cell wall, and within the exoskeleton of crustaceans, arthropods and helminth parasites [1]. In insects, chitin is an integral part of the cuticle and as such, expression of chitinases are essential for a successful cuticle molt and reorganisation of the chitin-extracellular matrix architecture [2-4]. Aside from developmental roles, chitinases are also used by pathogens to invade or exploit chitin-containing structures within lower organisms [5], highlighting the importance of chitinases during host-pathogen interactions. However, highly conserved chitinases are expressed across all species, even mammals that lack endogenous chitin and these species, chitinases are considered an evolutionary ancient form of host defence against chitincontaining pathogens and chitinous material [6-8]. CLPs on the other hand, are a diverse set of proteins often expressed in a species specific manner, and have arisen from gene duplication of chitinases followed by mutation and loss of function of the chitinolytic domain [9]. CLPs are strongly, but not exclusively, associated with T helper 2-type inflammatory pathologies that include helminth infection [10], asthma [11] and fibrosis [12], and as such a lot is known about their expression patterns during disease. However, the individual roles of CLPs during physiology versus inflammation and pathology are not well understood. Extensive phylogenetic analysis on the chitinase and CLP families has provided detailed insights into protein diversification across species, conserved protein features and gene specialisation $[9,13-15]$. CLPs are evolving at a remarkably rapid rate, which appears to be beyond the extent of natural genetic drift, and rather points toward positive selection forces that drive their genetic variation. However, whole CLP sequence estimations of synonymous versus non-synomyous mutations $(\omega<0.5)$ did not support such selection pressures [9]. Rather, it appears that there are specific sites within the CLP protein structure that are under positive selection pressures $(\omega>1)$ that drive the high functional diversity of CLPs across species, yet allow for conservation of the sugar-binding barrel structure [13]. This diversity is particularly highlighted between humans and mice (Figure 1) and scientists have questioned whether studies in mice yield useful information for human pathologies. However, despite the large diversity and whilst lacking 
chitin-degrading activity, mammalian CLPs are all widely associated with immune-modulating activities important for both pathogen control and corresponding host-damage $[10,16]$. These innate host-defence roles also extend to species other than mammals. For example, Drosophila express imaginal disc growth factor (IDGF) proteins, which are $\sim 25 \%$ homologous to mammalian CLPs (Figure 1) and recent studies have characterised functional readouts for IDGFs during nematode infection, wound injury and healing $[17,18]$. Similarly mollusk CLPs including My-Clp1 from Japanese scallops and Cg-Clp1 and -Clp2 from oysters appear equally involved in developmental tissue remodelling and immune defence $[19,20]$. CLPs across species are also broadly expressed in similar cell types (Table 1). In humans and mice, CLPs are expressed in both immune and structural cells whilst data from lower organisms points toward expression in haemocytes (immune cells) and structural tissues like larval body fat. Thus, despite the diversity, it is clear that a lot can be gained from studying CLP molecules across multiple species. Such experiments will provide a strong link between CLP functions and the evolutionary development of this fascinating family of proteins. Herein, this review will give examples of the innate immune responses influenced by CLPs, highlighting how these regulatory roles are important for balancing host-pathogen responses and the implications for disease pathology when this balance is not maintained.

\section{Disease association and molecular mechanisms of CLPs}

A brief search of the literature quickly highlights CLP expression in an enormous variety of pathologies or models suggesting broad generalised functions. The exception seem to be YKL-39 in humans and $\mathrm{Ym} 2$ in mice which appear to have restricted roles during arthritis/osteoarthritis [21-23] and airway induced inflammation [24-26] respectively. However, YKL-39 and Ym2 are not widely studied, so there may be key information missing that links these proteins to other physiological or pathological processes. At least in mice, studies are hampered by limited tools to detect or analyse $\mathrm{Ym} 2$, as this protein has high sequence similarity ( 95\%) to Ym1 (Figure 1) and is the least abundant murine CLP [10, 27].

YKL-40 is the best studied CLP in terms of disease associations with increased expression levels found in infection [28,29], fibrosis [30,31], multiple sclerosis [32], lung disease [33] and many more pathologies. Probably not surprisingly, BRP-39 in mice is often referred to as the "prototypical" CLP 
because it is the genetic orthologue of YKL-40 in humans. However, whilst BRP-39 is upregulated in various mouse models of infection and pathology, Ym1 seems to more closely mimic the effects of YKL-40 as it is often upregulated to a greater degree than BRP-39 and seems to share functional similarities to YKL-40 [10]. For example, both YKL-40 and Ym1 levels are greatly increased in the serum following injury, inflammation or in unbalanced immune responses [28,34]. Additionally, these two CLPs are expressed in neutrophils [35] and are increased following either IL-4/IL-13 or IFNy stimulation [36]. It is clear from both an evolutionary standpoint and from an immunological basis, that studying all CLPs in mice; Ym1, Ym2 and BRP-39 and the crossover of functions in other species; will be critical for understanding the driving forces behind CLP diversification and their role in disease.

A lot of current research aims to address the use of CLPs as indicators of pathology and/or disease severity [37-39], but are they more than just biomarkers of disease? The molecular mechanisms of CLPs that have so far been discovered support a diverse array of functions from altering collagen synthesis/degradation $[40,41]$ to regulating pro-inflammatory cytokine levels important for control of infection $[10,16]$. Primarily CLPs are carbohydrate binding molecules, but individual proteins often differ in the complexity of sugars they bind [42]. For instance, resolution of the Ym1 crystal structure and additional biochemical analysis revealed specific binding to heparin/heparan sulfate proteoglycans and possible interactions with glucosamine oligomers $[43,44]$. Although, later structural analysis appeared inconsistent with a monoglucosamine-binding site [45]. In contrast, YKL-39 binds chito-oligosaccharides, with sugar length determining binding strength [46]. Considering its apparent specialised functions, it is somewhat surprising that further studies have not begun to unlock mechanistic details of YKL-39.

Whilst one protein, 12/15-lipoxygenase, has been identified to bind $\mathrm{Ym1} / \mathrm{Ym}$, an interaction thought to mediate $\mathrm{Ym} 1 / \mathrm{Ym} 2$ effects on Th2-immune regulation [47], the spotlight has remained on understanding receptor-ligand interactions of YKL-40/BRP-39 and numerous binding partners have already been identified. Initially studies focussed on IL-13R $\alpha 2$ as a receptor for YKL-40/BRP-39 after an interaction was revealed using yeast two-hybrid screening [48]. However, many more targets were identified by this and later screening approaches. Prostaglandin D2 receptor (CRTH2) [49], receptor for advance glycation end product (RAGE) [50] and type I collagen $[40,41]$ have also been shown to interact 
with YKL-40/BRP-39. Some of these interactions appear to at least in part, be responsible for the regulatory actions of CLPs on innate immune responses and tissue remodelling and will be discussed in more detail below. However, it is clear that there are still actions of CLPs that have not yet been attributed to receptor-ligand interactions suggesting that there are likely more CLP receptors or alternative functions yet to be identified.

\section{CLP regulatory roles during innate inflammation}

Some of the most extensive functional or characterisation studies of CLPs has centred around asthma and related lung diseases. CLPs are highly upregulated in the lungs of asthmatic patients $[33,51,52]$ and in murine models of allergic airway inflammation [7,24,53]. The majority of studies have focused on how CLPs may be regulating adaptive Th2 responses during allergic inflammation [47,53]. However, YKL40 expression positively correlates to neutrophilic and IL-17-driven inflammation in asthmatic patients $[38,54]$, suggesting CLPs may also be important for non-Th2 asthma phenotypes that are often strongly associated with innate immune responses. Recently, we demonstrated that Ym1 (and to some extent Ym2) stimulates cytokine $I L-1 \beta$ to drive IL-17A production in innate $\gamma \delta T$ cells, resulting in the accumulation of neutrophils [10]. Ym1-induced neutrophilia was important for host-defence against nematode $N$. brasiliensis larvae that were migrating through the lung on route to the gastrointestinal tract. Whilst yet to be demonstrated directly, the influence of $Y m 1$ on IL-1 $\beta$ was proposed to occur through activation of the inflammasome $[10,55]$, a hypothesis consistent with the ability of Ym1 to form crystals under acidic and highly inflammatory conditions [35,56]. BRP-39 (Chil1) has also been shown to have proinflammatory effects, albeit during bacterial infection. Following Staphylococcus aureus infection of the bone and bone marrow, inhibition of Chilı via shRNA delivery dampened IL-1 $\beta$ and TNF $\alpha$ cytokine levels [57]. Similarly, Chil1-deficient mice had significantly lower levels of TNF $\alpha$, IL-6 and IL-22 in the large intestine following Salmonella enterica ser. Typhimurium infection [58]. Yet, unlike Ym1 where proinflammatory effects were associated with enhanced host-defence, BRP-39 in the gut and bone appears to be a pathogenic mediator enhancing bacterial survival $[57,58]$ and invasion [59]. Interestingly, in the lung BRP-39 inhibits caspase-1-dependent macrophage pyroptosis and thereby augments macrophage killing 
of Streptococcus pneumoniae [60]. BRP-39 not only limited pathogen survival/colonisation but also reduced $\mathrm{IL}-1 \beta$ production in a way that was consistent with inhibition of inflammasome activation, and thereby was important for the control of inflammation-induced pathology $[16,60]$. Whilst these findings are contradictory, differences may relate to contrasting BRP-39-protein interactions in different tissues or during different infections. For example, BRP-39 suppression of bacterial growth in the lung was found to be IL-13R 2 2-dependent [48], whereas bacterial adherence and invasion in the colon required direct binding of bacteria to epithelial cell derived BRP-39 [59,61]. Regardless, these studies highlight the complex nature of CLP regulatory roles and further studies are clearly needed to understand the mechanisms through which CLPs mediate pathogen related effects.

Overall studies in mice point toward Ym1 playing important innate defence roles during nematode infections $[10,62,63]$, whilst BRP-39 appears to have a greater role in bacterial infections $[16,60]$, adding to speculations that host-pathogen interactions may have influenced evolutionary divergence of CLPs in rodents. Examining the effects of CLPs in humans would suggest an overarching role of YKL-40 during infection, inflammation and pathology. Serum levels of YKL-40 increase during helminth $[28,64]$ and bacterial infection $[29,65]$ and whilst this hasn't necessarily been translated into a functional output, the absence of other similarly upregulated CLPs in humans suggests a dominant role for YKL-40 in these scenarios. Additionally, YKL-40 levels positively correlate with IL-1 $\beta$ expression following brain injury [66]. However, administration of recombinant YKL-40 to Streptococcus pneumoniae infected peritoneal macrophages from BRP-39-null mice reduced IL-1 $\beta$ secretion [48], again highlighting dual roles of CLPs during different innate immune responses. The ability of CLPs to influence innate immunity has also been described for organisms other than mammals. In particular the Drosophila IDGF family are critical regulatory molecules during innate immunity. Mutation of $I D G F_{3}$ leaves its host more susceptible to nematode or bacterial infection [17] and microarray analysis demonstrated that IDGF2 expression resulted in activation of innate immune genes associated with phagocytosis [18]. Similarly, following bacterial infection, mollusks rapidly upregulate $M y$-Clp1, a CLP gene with implicated roles in innate defence and pathogen recognition [19]. The complexities of specific CLP functions still need to be untangled but overall data suggests prominent roles in regulating innate immune responses and/or pathogen recognition. 
Not only important for host-defence, there is growing evidence that the innate immune system, in particular IL-1ß/inflammasome activation, play a pathogenic role during severe asthma [67-69]. Therefore, it is exciting to speculate a role for CLPs in such disease settings, where therapeutic inhibition of CLPs may be beneficial to pathological outcomes in asthma. In this respect, CLP functions already associated with infection-induced innate immune responses will help direct studies into diseases like asthma.

\section{Dual roles of CLPs in balancing tissue remodelling: protection from injury versus pathology}

CLPs have diverse effects on inflammation and immune regulation, but a lot of earlier studies often described CLP expression in relation to tissue injury, repair and remodelling [70-73]. In Drosophila, IDGF genes are increased upon septic injury [74] and IDGF3 regulates expression of genes required for wound closure after infectious nematodes force entry into the host [17]. In contrast in mice, BRP-39 levels increase after bacterial induced inflammation and injury $[16,60]$ and expression of Ymı triggers innate responses that contribute to tissue injury as a trade off to parasite killing [10]. However, increased levels of CLPs are not purely attributed to pathogen induced insult, as CLPs are also upregulated during sterile injury $[18,66,72,75,76]$ suggesting fundamental roles in tissue repair. It would appear that Ym1, and similarly other CLPs, have dual roles during injury and repair (Table 2). Th2-type immune responses have been shown to be critical for tissue repair following helminth infection [77]. Data strongly suggests that Ym1 can promote rapid lung regeneration by influencing Th2 cytokine production during $N$. brasiliensis infection, despite contributing to innate injury initially [10]. Additionally, Ym1 is highly expressed in neutrophils and is part of the neutrophil transcriptional signature that is critical for aiding the development of wound healing macrophages [78].

Current research has largely focused on the ability of CLPs to indirectly regulate tissue remodelling by influencing innate and/or adaptive immune responses. However, it is clear that CLPs can also influence the extracellular matrix (ECM) through direct interactions with ECM molecules, including collagen and heparan sulfate proteoglycans $[41,43,44]$. In vitro studies show that YKL-40 is mitogenic for fibroblasts [79] and it can induce cellular responses directly leading to enhanced collagen production [8o]. Such responses likely relate to the combined effects of YKL-40 binding to and stimulating collagen fibril 
formation [41], in addition inhibiting collagen degradation [40]. In fact enhanced expression of YKL-40 correlates with fibrotic disorders of the lung $[30,49,81]$ and liver $[31,82]$. Interestingly, YKL-40 also regulates the epithelial-mesenchymal transition (EMT) [83], a process which involves a phenotypic shift of epithelial cells towards a mesenchymal fibroblast-like cell that is highly migratory and secretes enhanced amounts of ECM proteins like collagen. EMT is not only a critical mechanism allowing cancer metastasis but has also been shown to be a key driver of airway remodelling in asthma [84]. Overall it is evident that CLPs affect the ECM both through immunoregulatory effects as well as through directly affecting ECM deposition and turnover. This has wide stretching consequences for tissue injury, repair and remodelling, not just as a consequence of host-defence responses but also as a pathological response in disease.

\section{Concluding remarks}

CLPs exert complex effects on tissue processes that are important for defence against pathogens and protection from the often destructive processes that occur after pathogen invasion. However, aberrant immune responses and prolonged and excessive CLP expression more often than not lead to detrimental disease outcomes. Understanding how CLPs maintain a balance between protective versus pathological responses (Figure 2) will be a critical step in determining how, when and what CLP functions can be targeted for disease therapy. Parallels between the roles of CLPs from lower organisms and mammals allow a unique opportunity to study how these proteins and particularly the functional domains of these proteins can act as over-arching molecules in development, homeostasis and pathology. There is still a long way to go before we will grasp the full repertoire of CLP effects, but analysis of functionalities across species and mechanism(s) of action will be a crucial step forward. Numerous protein-CLP receptor/ligand interactions have already been described and suggest CLPs have a somewhat promiscuous nature but also pose several interesting questions; (1) Do CLPs act on common receptor(s); (2) CLPs are expressed in such vast quantities and circulate throughout the body even during normal physiology. In these scenarios are innate CLPs pathogen sensing molecules and can these effects be attributed to receptor/ligand interactions?; and lastly (3) genetic mutations of YKL-40 have been associated with worse disease outcomes [85], but do these mutations alter protein binding interactions? Considering the 
duplication/mutation of chitinases to form the CLP family, it might be logical to assume that CLPs have evolved to recognise and interact with chitin-containing pathogens and initiate an immune response to deal with the threat. However, there must be alternative functions, as not all CLPs bind chitin and different CLPs expressed within one species can have quite dissimilar functions (Ym1 and BRP-39 in mice; YKL-39 and YKL-40 in humans). Perhaps multiple CLP genes evolved within a species to deal with different types of infectious agents and associated damage to the host, yet when produced in vast quantities in the absence of a concurrent infection, CLPs can lead to pathological consequences. Further experiments will be needed to answer these questions and those posed above and future CLP research will likely aim at discovering the true importance and therapeutic value of CLP molecules. 


\title{
Acknowledgements
}

The author thanks Prof. Judith Allen and Dr. Dominik Ruckerl from University of Manchester for critical reading of the manuscript.

\section{Funding}

The author is supported by a fellowship jointly funded by Medical Research Foundation and Asthma UK (MRFAUK-2015-302).

\section{Completing Interests}

The author declares that there are no competing interests associated with the manuscript.

\begin{abstract}
Abbreviations
CLP, chitinase-like protein; ECM, extracellular matrix; EMT, epithelial-mesenchymal transition; $\mathrm{GH}_{1}$, Glycoside hydrolase family 18 IDGF, imaginal disc growth factor.
\end{abstract}




\section{References}

[1] Tharanathan, R.N. and Kittur, F.S. (2003) Chitin--the undisputed biomolecule of great potential. Critical Reviews in Food Science and Nutrition, 43, 61-87.

http://dx.doi.org/10.1080/10408690390826455

[2] Pesch, Y.-Y., Riedel, D., Patil, K.R., Loch, G. and Behr, M. (2016) Chitinases and Imaginal disc growth factors organize the extracellular matrix formation at barrier tissues in insects. Nature Publishing Group, Nature Publishing Group. 6, 1-14. http://dx.doi.org/10.1038/srep18340

[3] Merzendorfer, H. and Zimoch, L. (2003) Chitin metabolism in insects: structure, function and regulation of chitin synthases and chitinases. The Journal of Experimental Biology, 206, 4393412.

[4] Xi, Y., Pan, P.-L., Ye, Y.-X., Yu, B., Xu, H.-J. and Zhang, C.-X. (2014) Chitinase-like gene family in the brown planthopper, Nilaparvata lugens. Insect Molecular Biology, 24, 29-40.

http://dx.doi.org/10.1111/imb.12133

[5] Shahabuddin, M., Toyoshima, T., Aikawa, M. and Kaslow, D.C. (1993) Transmission-blocking activity of a chitinase inhibitor and activation of malarial parasite chitinase by mosquito protease. Proceedings of the National Academy of Sciences of the United States of America, 90, 4266-70.

[6] Bishop, J.G., Dean, A.M. and Mitchell-Olds, T. (2000) Rapid evolution in plant chitinases: molecular targets of selection in plant-pathogen coevolution. Proceedings of the National Academy of Sciences of the United States of America, 97, 5322-7.

[7] Sutherland, T.E., Maizels, R.M. and Allen, J.E. (2009) Chitinases and chitinase-like proteins: potential therapeutic targets for the treatment of T-helper type 2 allergies. Clinical \& Experimental Allergy, 39, 943-55. http://dx.doi.org/10.1111/j.1365-2222.2009.03243.x

[8] Van Dyken, S.J., Liang, H.-E., Naikawadi, R.P., Woodruff, P.G., Wolters, P.J., Erle, D.J. et al. (2017) Spontaneous Chitin Accumulation in Airways and Age-Related Fibrotic Lung Disease. Cell, Elsevier Inc. 169, 497-501.e13. http://dx.doi.org/10.1016/j.cell.2017.03.044

[9] Bussink, A.P., Speijer, D., Aerts, J.M.F.G. and Boot, R.G. (2007) Evolution of mammalian chitinase(-like) members of family 18 glycosyl hydrolases. Genetics, 177, 959-70. http://dx.doi.org/10.1534/genetics.107.075846

[10] Sutherland, T.E., Logan, N., Ruckerl, D., Humbles, A.A., Allan, S.M., Papayannopoulos, V. et al. (2014) Chitinase-like proteins promote IL-17-mediated neutrophilia in a tradeoff between nematode killing and host damage. Nature Immunology, 15, 1116-25.

http://dx.doi.org/10.1038/ni.3023

[11] Komi, D.E.A., Kazemi, T. and Bussink, A.P. (2016) New Insights Into the Relationship Between Chitinase-3-Like-1 and Asthma. Current Allergy and Asthma Reports, Current Allergy and Asthma Reports. 16, 57-10. http://dx.doi.org/10.1007/s11882-016-0637-2

[12] Turn, C.S. and Kolliputi, N. (2014) Two sides of a coin: the dual roles of chitinase 3 -like 1 in idiopathic pulmonary fibrosis. Lung, Springer US. 192, 825-7. http://dx.doi.org/10.1007/s00408014-9651-0 
[13] Hussain, M. and Wilson, J.B. (2013) New Paralogues and Revised Time Line in the Expansion of the Vertebrate GH18 Family. Journal of Molecular Evolution, 76, 240-60.

http://dx.doi.org/10.1007/s00239-013-9553-4

[14] Huang, Q.-S., Xie, X.-L., Liang, G., Gong, F., Wang, Y., Wei, X.-O. et al. (2012) The GH18 family of chitinases: their domain architectures, functions and evolutions. Glycobiology, 22, 23-34. http://dx.doi.org/10.1093/glycob/cwrog2

[15] Funkhouser, J.D. and Aronson, N.N. (2007) Chitinase family GH18: evolutionary insights from the genomic history of a diverse protein family. BMC Evolutionary Biology, 7, 96.

http://dx.doi.org/10.1186/1471-2148-7-96

[16] Marion, C.R., Wang, J., Sharma, L., Losier, A., Lui, W., Andrews, N. et al. (2016) Chitinase 3-like1 (Chil1) Regulates Survival and Macrophage-mediated IL-1 $\beta$ and TNF- $\alpha$ during Pseudomonas Pneumonia. Infection and Immunity, American Society for Microbiology. IAl.00055-16. http://dx.doi.org/10.1128/IAl.00055-16

[17] Kucerova, L., Broz, V., Arefin, B., Maaroufi, H.O., Hurychova, J., Strnad, H. et al. (2016) The Drosophila Chitinase-Like Protein IDGF 3 Is Involved in Protection against Nematodes and in Wound Healing. Journal of Innate Immunity, Karger Publishers. 8, 199-210. http://dx.doi.org/10.1159/000442351

[18] Broz, V., Kucerova, L., Rouhova, L., Fleischmannova, J., Strnad, H., Bryant, P.J. et al. (2017) Drosophila imaginal disc growth factor 2 is a trophic factor involved in energy balance, detoxification, and innate immunity. Nature Publishing Group, Nature Publishing Group. 7, 1-15. http://dx.doi.org/10.1038/srep43273

[19] Gao, L., Xu, G.J., Su, H., Gao, X.G., Li, Y.F., Bao, X.B. et al. (2014) Identification and expression analysis of CDNA encoding chitinase-like protein (CLP) gene in Japanese scallop Mizuhopecten yessoensis. Genetics and Molecular Research, 13, 10727-40.

http://dx.doi.org/10.4238/2014.December.18.14

[20] Badariotti, F., Lelong, C., Dubos, M.-P. and Favrel, P. (2007) Characterization of chitinase-like proteins ( $\mathrm{Cg}$ - $\mathrm{Clp} 1$ and $\mathrm{Cg}$ - $\mathrm{Clp} 2$ ) involved in immune defence of the mollusc Crassostrea gigas. The FEBS Journal, Blackwell Publishing Ltd. 274, 3646-54. http://dx.doi.org/10.1111/j.17424658.2007.05898.x

[21] Knorr, T., Obermayr, F., Bartnik, E., Zien, A. and Aigner, T. (2003) YKL-39 (chitinase 3-like protein 2), but not YKL-40 (chitinase 3 -like protein 1), is up regulated in osteoarthritic chondrocytes. Annals of the Rheumatic Diseases, 62, 995-8.

http://dx.doi.org/10.1136/ard.62.10.995

[22] Steck, E., Breit, S., Breusch, S.J., Axt, M. and Richter, W. (2002) Enhanced expression of the human chitinase 3-like 2 gene (YKL-39) but not chitinase 3-like 1 gene (YKL-40) in osteoarthritic cartilage. Biochemical and Biophysical Research Communications, 299, 109-15.

[23] Miyatake, K., Tsuji, K., Yamaga, M., Yamada, J., Matsukura, Y., Abula, K. et al. (2013) Human YKL39 (chitinase 3-like protein 2), an osteoarthritis-associated gene, enhances proliferation and type II collagen expression in ATDC 5 cells. Biochemical and Biophysical Research Communications, 431, 52-7. http://dx.doi.org/10.1016/j.bbrc.2012.12.094

[24] Webb, D.C., McKenzie, A.N. and Foster, P.S. (2001) Expression of the Ym2 lectin-binding protein is dependent on interleukin (IL)- 4 and IL-13 signal transduction: identification of a novel allergy-associated protein. The Journal of Biological Chemistry, American Society for Biochemistry and Molecular Biology. 276, 41969-76. http://dx.doi.org/10.1074/jbc.M106223200 
[25] Song, H.-M., Jang, A.-S., Ahn, M.-H., Takizawa, H., Lee, S.-H., Kwon, J.-H. et al. (2008) Ym1 and Ym2 expression in a mouse model exposed to diesel exhaust particles. Environmental Toxicology, 23, 110-6. http://dx.doi.org/10.1002/tox.20319

[26] Kumagai, K., Lewandowski, R., Jackson-Humbles, D.N., Li, N., Van Dyken, S.J., Wagner, J.G. et al. (2016) Ozone-Induced Nasal Type 2 Immunity in Mice Is Dependent on Innate Lymphoid Cells. American Journal of Respiratory Cell and Molecular Biology, 54, 782-91. http://dx.doi.org/10.1165/rcmb.2015-01180C

[27] Ohno, M., Kida, Y., Sakaguchi, M., Sugahara, Y. and Oyama, F. (2014) Establishment of a quantitative PCR system for discriminating chitinase-like proteins: catalytically inactive breast regression protein-39 and Ym1 are constitutive genes in mouse lung. BMC Molecular Biology, 15, 23-12. http://dx.doi.org/10.1186/1471-2199-15-23

[28] Appleby, L.J., Nausch, N., Bourke, C.D., Rujeni, N., Midzi, N., Mduluza, T. et al. (2012) Chitinase 3-like 1 protein levels are elevated in Schistosoma haematobium infected children. Davies SJ, editor. PLoS Neglected Tropical Diseases, Public Library of Science. 6, e1898. http://dx.doi.org/10.1371/journal.pntd.0001898

[29] Kronborg, G., Ostergaard, C., Weis, N., Nielsen, H., Obel, N., Pedersen, S.S. et al. (2002) Serum level of YKL-40 is elevated in patients with Streptococcus pneumoniae bacteremia and is associated with the outcome of the disease. Scandinavian Journal of Infectious Diseases, 34, 3236. http://dx.doi.org/10.1080/00365540110080233

[30] Furuhashi, K., Suda, T., Nakamura, Y., Inui, N., Hashimoto, D., Miwa, S. et al. (2010) Increased expression of YKL-40, a chitinase-like protein, in serum and lung of patients with idiopathic pulmonary fibrosis. Respiratory Medicine, 104, 1204-10.

http://dx.doi.org/10.1016/j.rmed.2010.02.026

[31] Kumagai, E., Mano, Y., Yoshio, S., Shoji, H., Sugiyama, M., Korenaga, M. et al. (2016) Serum YKL-40 as a marker of liver fibrosis in patients with non-alcoholic fatty liver disease. Nature Publishing Group, Nature Publishing Group. 6, 35282. http://dx.doi.org/10.1038/srep35282

[32] Burman, J., Raininko, R., Blennow, K., Zetterberg, H., Axelsson, M. and Malmeström, C. (2016) $\mathrm{YKL}-40$ is a CSF biomarker of intrathecal inflammation in secondary progressive multiple sclerosis. Journal of Neuroimmunology, 292, 52-7.

http://dx.doi.org/10.1016/j.jneuroim.2016.01.013

[33] Mack, I., Hector, A., Ballbach, M., Kohlhäufl, J., Fuchs, K.J., Weber, A. et al. (2015) The role of chitin, chitinases, and chitinase-like proteins in pediatric lung diseases. Molecular and Cellular Pediatrics, Springer Berlin Heidelberg. 2, 3. http://dx.doi.org/10.1186/s40348-015-0014-6

[34] Ober, C., Tan, Z., Sun, Y., Possick, J.D., Pan, L., Nicolae, R. et al. (2008) Effect of variation in $\mathrm{CH}_{3} \mathrm{~L} 1$ on serum YKL-40 level, risk of asthma, and lung function. The New England Journal of Medicine, 358, 1682-91. http://dx.doi.org/10.1056/NEJMoa0708801

[35] Harbord, M., Novelli, M., Canas, B., Power, D., Davis, C., Godovac-Zimmermann, J. et al. (2002) $\mathrm{Ym} 1$ is a neutrophil granule protein that crystallizes in p47phox-deficient mice. The Journal of Biological Chemistry, 277, 5468-75. http://dx.doi.org/10.1074/jbc.M110635200

[36] Lee, C.G., Da Silva, C.A., Cruz, Dela, C.S., Ahangari, F., Ma, B., Kang, M.J. et al. (2011) Role of chitin and chitinase/chitinase-like proteins in inflammation, tissue remodeling, and injury. Annual Review of Physiology, 73, 479-501. http://dx.doi.org/10.1146/annurev-physiol-012110142250 
[37] Chen, G., Yang, T., Gu, Q., Ni, X.-H., Zhao, Z.-H., Ye, J. et al. (2014) Elevated plasma YKL-40 as a prognostic indicator in patients with idiopathic pulmonary arterial hypertension. Respirology (Carlton, Vic), 19, 608-15. http://dx.doi.org/10.1111/resp.12283

[38] Konradsen, J.R., James, A., Nordlund, B., Reinius, L.E., Söderhäll, C., Melén, E. et al. (2013) The chitinase-like protein YKL-40: a possible biomarker of inflammation and airway remodeling in severe pediatric asthma. The Journal of Allergy and Clinical Immunology, 132, 328-35.e5. http://dx.doi.org/10.1016/j.jaci.2013.03.003

[39] Zhu, C.-B., Chen, L.-L., Tian, J.-J., Su, L., Wang, C., Gai, Z.-T. et al. (2012) Elevated serum YKL40 level predicts poor prognosis in hepatocellular carcinoma after surgery. Annals of Surgical Oncology, Springer-Verlag. 19, 817-25. http://dx.doi.org/10.1245/s10434-011-2026-3

[40] Iwata, T., Kuwajima, M., Sukeno, A., Ishimaru, N., Hayashi, Y., Wabitsch, M. et al. (2009) YKL-40 secreted from adipose tissue inhibits degradation of type I collagen. Biochemical and Biophysical Research Communications, 388, 511-6. http://dx.doi.org/10.1016/j.bbrc.2009.08.024

[41] Bigg, H.F., Wait, R., Rowan, A.D. and Cawston, T.E. (2006) The mammalian chitinase-like lectin, YKL-40, binds specifically to type I collagen and modulates the rate of type I collagen fibril formation. The Journal of Biological Chemistry, 281, 21082-95. http://dx.doi.org/10.1074/jbc.M601153200

[42] Kzhyshkowska, J., Yin, S., Liu, T., Riabov, V. and Mitrofanova, I. (2016) Role of chitinase-like proteins in cancer. Biological Chemistry, 397, 231-47. http://dx.doi.org/10.1515/hsz-2015-0269

[43] Sun, Y.J., Chang, N.C., Hung, S.I., Chang, A.C., Chou, C.C. and Hsiao, C.D. (2001) The crystal structure of a novel mammalian lectin, Ym1, suggests a saccharide binding site. The Journal of Biological Chemistry, American Society for Biochemistry and Molecular Biology. 276, 17507-14. http://dx.doi.org/10.1074/jbc.Mo10416200

[44] Chang, N.C., Hung, S.I., Hwa, K.Y., Kato, I., Chen, J.E., Liu, C.H. et al. (2001) A macrophage protein, $\mathrm{Ym} 1$, transiently expressed during inflammation is a novel mammalian lectin. The Journal of Biological Chemistry, 276, 17497-506. http://dx.doi.org/10.1074/jbc.Mo10417200

[45] Tsai, M.-L., Liaw, S.-H. and Chang, N.-C. (2004) The crystal structure of Ym1 at $1.31 \mathrm{~A}$ resolution. Journal of Structural Biology, 148, 290-6. http://dx.doi.org/10.1016/j.jsb.2004.07.002

[46] Ranok, A., Wongsantichon, J., Robinson, R.C. and Suginta, W. (2015) Structural and thermodynamic insights into chitooligosaccharide binding to human cartilage chitinase 3 -like protein 2 (CHI3L2 or YKL-39). Journal of Biological Chemistry, American Society for Biochemistry and Molecular Biology. 290, 2617-29. http://dx.doi.org/10.1074/jbc.M114.588905

[47] Cai, Y., Kumar, R.K., Zhou, J., Foster, P.S. and Webb, D.C. (2009) Ym1/2 Promotes Th2 Cytokine Expression by Inhibiting 12/15(S)-Lipoxygenase: Identification of a Novel Pathway for Regulating Allergic Inflammation. The Journal of Immunology, 182, 5393-9. http://dx.doi.org/10.4049/jimmunol.0803874

[48] He, C.H., Lee, C.G., Cruz, Dela, C.S., Lee, C.-M., Zhou, Y., Ahangari, F. et al. (2013) Chitinase 3like 1 regulates cellular and tissue responses via IL-13 receptor $\alpha 2$. CellReports, 4, 830-41. http://dx.doi.org/10.1016/j.celrep.2013.07.032

[49] Zhou, Y., He, C.H., Herzog, E.L., Peng, X., Lee, C.-M., Nguyen, T.H. et al. (2015) Chitinase 3-like1 and its receptors in Hermansky-Pudlak syndrome-associated lung disease. The Journal of Clinical Investigation, American Society for Clinical Investigation. 125, 3178-92.

http://dx.doi.org/10.1172/JCl79792 
[50] Low, D., Subramaniam, R., Lin, L., Aomatsu, T., Mizoguchi, A., Ng, A. et al. (2015) Chitinase 3like 1 induces survival and proliferation of intestinal epithelial cells during chronic inflammation and colitis-associated cancer by regulating S100Ag. Oncotarget, Impact Journals. 6, 36535-50. http://dx.doi.org/10.18632/oncotarget.5440

[51] Specjalski, K., Chełmińska, M. and Jassem, E. (2015) YKL-40 protein correlates with the phenotype of asthma. Lung, Springer US. 193, 189-94. http://dx.doi.org/10.1007/s00408-0159693-y

[52] James, A.J., Reinius, L.E., Verhoek, M., Gomes, A., Kupczyk, M., Hammar, U. et al. (2016) Increased YKL-40 and Chitotriosidase in Asthma and Chronic Obstructive Pulmonary Disease. American Journal of Respiratory and Critical Care Medicine, 193, 131-42. http://dx.doi.org/10.1164/rccm.201504-0760OC

[53] Lee, C.G., Hartl, D., Lee, G.R., Koller, B., Matsuura, H., Da Silva, C.A. et al. (2009) Role of breast regression protein 39 (BRP-39)/chitinase 3 -like-1 in Th2 and IL-13-induced tissue responses and apoptosis. The Journal of Experimental Medicine, 206, 1149-66.

http://dx.doi.org/10.1084/jem.20081271

[54] Chupp, G.L., Lee, C.G., Jarjour, N., Shim, Y.M., Holm, C.T., He, S. et al. (2007) A chitinase-like protein in the lung and circulation of patients with severe asthma. The New England Journal of Medicine, 357, 2016-27. http://dx.doi.org/10.1056/NEJMoa0736oo

[55] Muallem, G. and Hunter, C.A. (2014) ParadYm shift: Ym1 and Ym2 as innate immunological regulators of IL-17. Nature Immunology, Nature Publishing Group. 15, 1099-100.

http://dx.doi.org/10.1038/ni.3032

[56] Marchesi, F., Monestiroli, S.V., Capillo, M., Gobbi, A., Minucci, S., Pelicci, P.G. et al. (2003) Eosinophilic crystals as a distinctive morphologic feature of a hyaline droplet nephropathy in a mouse model of acute myelogenous leukaemia. Journal of Veterinary Medicine a, Physiology, Pathology, Clinical Medicine, 50, 103-7.

[57] Chen, X., Jiao, J., He, X., Zhang, J., Wang, H., Xu, Y. et al. (2017) CHI3L1 regulation of inflammation and the effects on osteogenesis in a Staphylococcus aureus-induced murine model of osteomyelitis. The FEBS Journal, 284, 1738-47. http://dx.doi.org/10.1111/febs.14082

[58] Tran, H.T., Lee, I.-A., Low, D., Kamba, A., Mizoguchi, A., Shi, H.N. et al. (2014) Chitinase 3-like 1 Synergistically Activates IL6-mediated STAT3 Phosphorylation in Intestinal Epithelial Cells in Murine Models of Infectious Colitis. Inflammatory Bowel Diseases, 20, 835-46.

http://dx.doi.org/10.1097/MIB.0000000000000033

[59] Mizoguchi, E. (2006) Chitinase 3-Like-1 Exacerbates Intestinal Inflammation by Enhancing Bacterial Adhesion and Invasion .... Gastroenterology.

[6o] Cruz, Dela, C.S., Liu, W., He, C.H., Jacoby, A., Gornitzky, A., Ma, B. et al. (2012) Chitinase 3-like1 promotes Streptococcus pneumoniae killing and augments host tolerance to lung antibacterial responses. Cell Host \& Microbe, 12, 34-46.

http://dx.doi.org/10.1016/j.chom.2012.05.017

[61] Low, D., Tran, H.T., Lee, I.-A., Dreux, N., Kamba, A., Reinecker, H.-C. et al. (2013) Chitin-binding domains of Escherichia coli ChiA mediate interactions with intestinal epithelial cells in mice with colitis. Gastroenterology, 145, 602-9. http://dx.doi.org/10.1053/j.gastro.2013.05.017

[62] Nair, M.G., Gallagher, I.J., Taylor, M.D., Loke, P., Coulson, P.S., Wilson, R.A. et al. (2005) Chitinase and Fizz Family Members Are a Generalized Feature of Nematode Infection with 
Selective Upregulation of Ym1 and Fizz1 by Antigen-Presenting Cells. Infection and Immunity, American Society for Microbiology. 73, 385-94. http://dx.doi.org/10.1128/IAI.73.1.385-394.2005

[63] Reece, J.J., Siracusa, M.C. and Scott, A.L. (2006) Innate immune responses to lung-stage helminth infection induce alternatively activated alveolar macrophages. 74, 4970-81. http://dx.doi.org/10.1128/IAl.00687-06

[64] Broadhurst, M.J., Leung, J.M., Kashyap, V., McCune, J.M., Mahadevan, U., McKerrow, J.H. et al. (2010) IL-22+ $\mathrm{CD}_{4}+\mathrm{T}$ cells are associated with therapeutic trichuris trichiura infection in an ulcerative colitis patient. Science Translational Medicine, American Association for the Advancement of Science. 2, 6ora88-8. http://dx.doi.org/10.1126/scitrans/med.3001500

[65] Spoorenberg, S.M.C., Vestjens, S.M.T., Rijkers, G.T., Meek, B., van Moorsel, C.H.M., Grutters, J.C. et al. (2017) YKL-40, CCL18 and SP-D predict mortality in patients hospitalized with community-acquired pneumonia. Respirology (Carlton, Vic), John Wiley \& Sons, Ltd. 22, 542-50. http://dx.doi.org/10.1111/resp.12924

[66] Bonneh-Barkay, D., Zagadailov, P., Zou, H., Niyonkuru, C., Figley, M., Starkey, A. et al. (2010) YKL-40 expression in traumatic brain injury: an initial analysis. Journal of Neurotrauma, 27, 1215-23. http://dx.doi.org/10.1089/neu.2010.1310

[67] PhD, C.R., PhD, S.P., MBBS, U.H., MBBS, C.-H.K., PhD, C.W., PhD, K.R. et al. (2017) Sputum transcriptomics reveal upregulation of $\mathrm{IL}-1$ receptor family members in patients with severe asthma. Journal of Allergy and Clinical Immunology, Elsevier Inc. 1-11.

http://dx.doi.org/10.1016/j.jaci.2017.02.045

[68] Kim, R.Y., Pinkerton, J.W., Essilfie, A.T., Robertson, A.A.B., Baines, K.J., Brown, A.C. et al. (2017) Role for NLRP 3 Inflammasome-mediated, IL-1 $\beta$-Dependent Responses in Severe, Steroid-Resistant Asthma. American Journal of Respiratory and Critical Care Medicine, 196, 28397. http://dx.doi.org/10.1164/rccm.201609-1830OC

[69] Simpson, J.L., Phipps, S., Baines, K.J., Oreo, K.M., Gunawardhana, L. and Gibson, P.G. (2014) Elevated expression of the $\mathrm{NLRP}_{3}$ inflammasome in neutrophilic asthma. European Respiratory Journal, European Respiratory Society. 43, 1067-76.

http://dx.doi.org/10.1183/og031936.00105013

[70] Jacques, C., Recklies, A.D., Levy, A. and Berenbaum, F. (2007) HC-gp39 contributes to chondrocyte differentiation by inducing $\mathrm{SOX}_{9}$ and type II collagen expressions. Osteoarthritis and Cartilage, 15, 138-46. http://dx.doi.org/10.1016/j.joca.2006.07.003

[71] Giannetti, N., Moyse, E., Ducray, A., Bondier, J.-R., Jourdan, F., Propper, A. et al. (2004) Accumulation of $\mathrm{Ym} 1 / 2$ protein in the mouse olfactory epithelium during regeneration and aging. Neuroscience, 123, 907-17.

[72] Hung, S.-I., Chang, A.C., Kato, I. and Chang, N.-C.A. (2002) Transient expression of Ym1, a heparin-binding lectin, during developmental hematopoiesis and inflammation. Journal of Leukocyte Biology, 72, 72-82.

[73] Johansen, J.S., Jensen, H.S. and Price, P.A. (1993) A new biochemical marker for joint injury. Analysis of YKL-40 in serum and synovial fluid. British Journal of Rheumatology, 32, 949-55.

[74] De Gregorio, E., Spellman, P.T., Rubin, G.M. and Lemaitre, B. (2001) Genome-wide analysis of the Drosophila immune response by using oligonucleotide microarrays. Proceedings of the National Academy of Sciences of the United States of America, National Acad Sciences. 98, 12590-5. http://dx.doi.org/10.1073/pnas.221458698 
[75] Murase, T., Yamamoto, T., Koide, A., Yagi, Y., Kagawa, S., Tsuruya, S. et al. (2017) Temporal expression of chitinase-like 3 in wounded murine skin. International Journal of Legal Medicine, International Journal of Legal Medicine. 1-9. http://dx.doi.org/10.1007/s00414-017-1658-7

[76] Loke, P., Gallagher, I., Nair, M.G., Zang, X., Brombacher, F., Mohrs, M. et al. (2007) Alternative activation is an innate response to injury that requires $\mathrm{CD}_{4}+\mathrm{T}$ cells to be sustained during chronic infection. Journal of Immunology (Baltimore, Md : 1950), 179, 3926-36.

[77] Chen, F., Liu, Z., Wu, W., Rozo, C., Bowdridge, S., Millman, A. et al. (2012) An essential role for $\mathrm{TH}_{2}$-type responses in limiting acute tissue damage during experimental helminth infection. 18, 26o-6. http://dx.doi.org/10.1038/nm.2628

[78] Chen, F., Wu, W., Millman, A., Craft, J.F., Chen, E., Patel, N. et al. (2014) Neutrophils prime a long-lived effector macrophage phenotype that mediates accelerated helminth expulsion. Nature Immunology, 15, 938-46. http://dx.doi.org/10.1038/ni.2984

[79] De Ceuninck, F., Gaufillier, S., Bonnaud, A., Sabatini, M., Lesur, C. and Pastoureau, P. (2001) YKL-40 (cartilage gP-39) induces proliferative events in cultured chondrocytes and synoviocytes and increases glycosaminoglycan synthesis in chondrocytes. Biochemical and Biophysical Research Communications, 285, 926-31. http://dx.doi.org/10.1006/bbrc.2001.5253

[80] Park, S.J., Jun, Y.J., Kim, T.-H., Jung, J.Y., Hwang, G.H., Jung, K.J. et al. (2013) Increased expression of $\mathrm{YKL}-4 \mathrm{O}$ in mild and moderate/severe persistent allergic rhinitis and its possible contribution to remodeling of nasal mucosa. American Journal of Rhinology \& Allergy, 27, 3728o. http://dx.doi.org/10.2500/ajra.2013.27.3941

[81] Väänänen, T., Lehtimäki, L., Vuolteenaho, K., Hämäläinen, M., Oksa, P., Vierikko, T. et al. (2017) Glycoprotein YKL-40 Levels in Plasma Are Associated with Fibrotic Changes on HRCT in Asbestos-Exposed Subjects. Mediators of Inflammation, 2017, 1-7. http://dx.doi.org/10.1155/2017/1797512

[82] Tao, H., Yang, J.-J., Shi, K.-H., Huang, C., Zhang, L., Lv, X.-W. et al. (2014) The significance of YKL-40 protein in liver fibrosis. Inflammation Research : Official Journal of the European Histamine Research Society [Et Al], Springer Basel. 63, 249-54. http://dx.doi.org/10.1007/s00011-013-0698-9

[83] Jefri, M. (2015) YKL-40 regulated epithelial-mesenchymal transition and migration/invasion enhancement in non-small cell lung cancer. BMC Cancer, BMC Cancer. 15, 1-10. http://dx.doi.org/10.1186/s12885-015-1592-3

[84] Pain, M., Bermudez, O., Lacoste, P., Royer, P.-J., Botturi, K., Tissot, A. et al. (2014) Tissue remodelling in chronic bronchial diseases: from the epithelial to mesenchymal phenotype. European Respiratory Review : an Official Journal of the European Respiratory Society, European Respiratory Society. 23, 118-30. http://dx.doi.org/10.1183/09059180.00004413

[85] Ober, C. and Chupp, G.L. (2009) The chitinase and chitinase-like proteins: a review of genetic and functional studies in asthma and immune-mediated diseases. Current Opinion in Allergy and Clinical Immunology, 9, 401-8. http://dx.doi.org/10.1097/ACl.obo13e3283306533

[86] Puthumana, J., Hall, I.E., Reese, P.P., Schröppel, B., Weng, F.L., Thiessen-Philbrook, H. et al. (2017) YKL-40 Associates with Renal Recovery in Deceased Donor Kidney Transplantation. Journal of the American Society of Nephrology : JASN, American Society of Nephrology. 28, 66170. http://dx.doi.org/10.1681/ASN.2016010091

[87] Hall, I.E., Stern, E.P., Cantley, L.G., Elias, J.A. and Parikh, C.R. (2014) Urine YKL-40 is associated 
with progressive acute kidney injury or death in hospitalized patients. BMC Nephrology, BioMed Central. 15, 133. http://dx.doi.org/10.1186/1471-2369-15-133

[88] Suh, J.-S., Kim, S.-H., Cho, K.S., Jung, I.-A., Cho, W.K., Jeon, Y.J. et al. (2016) Urinary markers in the early stage of nephropathy in patients with childhood-onset type 1 diabetes. Pediatric Nephrology (Berlin, Germany), Springer Berlin Heidelberg. 31, 623-31. http://dx.doi.org/10.1007/s00467-015-3253-9

[89] Pizano-Martínez, O., Yañez-Sánchez, I., Alatorre-Carranza, P., Miranda-Díaz, A., OrtizLazareno, P.C., García-Iglesias, T. et al. (2011) YKL-40 expression in $\mathrm{CD}_{14}{ }^{+}$liver cells in acute and chronic injury. World Journal of Gastroenterology : WJG, 17, 3830-5. http://dx.doi.org/10.3748/wjg.v17.i33.3830

[90] Vos, K., Steenbakkers, P., Miltenburg, A.M., Bos, E., van Den Heuvel, M.W., van Hogezand, R.A. et al. (2000) Raised human cartilage glycoprotein-39 plasma levels in patients with rheumatoid arthritis and other inflammatory conditions. Annals of the Rheumatic Diseases, BMJ Publishing Group. 59, 544-8. http://dx.doi.org/10.1136/ard.59.7.544

[91] Johansen, J.S., Hvolris, J., Hansen, M., Backer, V., Lorenzen, I. and Price, P.A. (1996) Serum YKL-40 levels in healthy children and adults. Comparison with serum and synovial fluid levels of YKL-40 in patients with osteoarthritis or trauma of the knee joint. British Journal of Rheumatology, 35, 553-9.

[92] Zhou, Y., Peng, H., Sun, H., Peng, X., Tang, C., Gan, Y. et al. (2014) Chitinase 3-like 1 suppresses injury and promotes fibroproliferative responses in Mammalian lung fibrosis. Science Translational Medicine, American Association for the Advancement of Science. 6, 240ra76-6. http://dx.doi.org/10.1126/scitranslmed.3007096

[93] Syed, M.A. and Bhandari, V. (2013) Hyperoxia exacerbates postnatal inflammation-induced lung injury in neonatal BRP-39 null mutant mice promoting the M1 macrophage phenotype. Mediators of Inflammation, Hindawi. 2013, 457189-12. http://dx.doi.org/10.1155/2013/457189

[94] Schmidt, I.M., Hall, I.E., Kale, S., Lee, S., He, C.H., Lee, Y. et al. (2013) Chitinase-like protein Brp39/YKL-40 modulates the renal response to ischemic injury and predicts delayed allograft function. Journal of the American Society of Nephrology: JASN, American Society of Nephrology. 24, 309-19. http://dx.doi.org/10.1681/ASN.2012060579

[95] Maddens, B., Ghesquière, B., Vanholder, R., Demon, D., Vanmassenhove, J., Gevaert, K. et al. (2012) Chitinase-like proteins are candidate biomarkers for sepsis-induced acute kidney injury. Molecular \& Cellular Proteomics, American Society for Biochemistry and Molecular Biology. 11, M111.013094. http://dx.doi.org/10.1074/mcp.M111.013094

[96] Rehli, M., Krause, S.W. and Andreesen, R. (1997) Molecular characterization of the gene for human cartilage gp-39 ( $\left.\mathrm{CH}_{3} \mathrm{~L} 1\right)_{1}$, a member of the chitinase protein family and marker for late stages of macrophage differentiation. Genomics, 43, 221-5. http://dx.doi.org/10.1006/geno.1997.4778

[97] Lee, C.G., Hartl, D., Lee, G.R., Koller, B., Matsuura, H., Da Silva, C.A. et al. (2009) Role of breast regression protein 39 (BRP-39)/chitinase 3 -like-1 in Th2 and IL-13-induced tissue responses and apoptosis. The Journal of Experimental Medicine, 206, 1149-66.

http://dx.doi.org/10.1084/jem.20081271

[98] Falcone, F.H., Loke, P., Zang, X., MacDonald, A.S., Maizels, R.M. and Allen, J.E. (2001) A Brugia malayi homolog of macrophage migration inhibitory factor reveals an important link between macrophages and eosinophil recruitment during nematode infection. Journal of Immunology 
(Baltimore, Md : 1950), 167, 5348-54.

[99] Volck, B., Price, P.A., Johansen, J.S., Sørensen, O., Benfield, T.L., Nielsen, H.J. et al. (1998) YKL40, a mammalian member of the chitinase family, is a matrix protein of specific granules in human neutrophils. Proceedings of the Association of American Physicians, 110, 351-60.

[100] Nikota, J.K., Botelho, F.M., Bauer, C.M., Jordana, M., Coyle, A.J., Humbles, A.A. et al. (2011) Differential expression and function of breast regression protein 39 (BRP-39) in murine models of subacute cigarette smoke exposure and allergic airway inflammation. Respiratory Research, 12, 39. http://dx.doi.org/10.1186/1465-9921-12-39

[101] Park, J.-A., Drazen, J.M. and Tschumperlin, D.J. (2010) The Chitinase-like Protein YKL-40 Is Secreted by Airway Epithelial Cells at Base Line and in Response to Compressive Mechanical Stress. The Journal of Biological Chemistry, 285, 29817-25. http://dx.doi.org/10.1074/jbc.M110.103416

[102] Ward, J.M., Yoon, M., Anver, M.R., Haines, D.C., Kudo, G., Gonzalez, F.J. et al. (2001) Hyalinosis and $\mathrm{Ym}_{1} / \mathrm{Ym}_{2}$ gene expression in the stomach and respiratory tract of $129 \mathrm{~S}_{4} / \mathrm{SvJae}$ and wildtype and CYP1A2-null B6, 129 mice. The American Journal of Pathology, 158, 323-32.

[103] Di Rosa, M., Tibullo, D., Saccone, S., Distefano, G., Basile, M.S., Di Raimondo, F. et al. (2016) $\mathrm{CH}_{3} \mathrm{~L} 1$ nuclear localization in monocyte derived dendritic cells. Immunobiology, 221, 347-56. http://dx.doi.org/10.1016/j.imbio.2015.09.023

[104] Xu, Q., Chai, S.-J., Qian, Y.-Y., Zhang, M. and Wang, K. (2012) Breast regression protein-39 (BRP-39) promotes dendritic cell maturation in vitro and enhances Th2 inflammation in murine model of asthma. Acta Pharmacologica Sinica, 33, 1525-32.

http://dx.doi.org/10.1038/aps.2012.154

[105] Arora, M., Chen, L., Paglia, M., Gallagher, I., Allen, J.E., Vyas, Y.M. et al. (2006) Simvastatin promotes Th2-type responses through the induction of the chitinase family member $Y \mathrm{~m} 1$ in dendritic cells. Proceedings of the National Academy of Sciences of the United States of America, 103, 7777-82. http://dx.doi.org/10.1073/pnas.0508492103

[106] Johansen, J.S., Olee, T., Price, P.A., Hashimoto, S., Ochs, R.L. and Lotz, M. (2001) Regulation of YKL-40 production by human articular chondrocytes. Arthritis and Rheumatism, John Wiley \& Sons, Inc. 44, 826-37. http://dx.doi.org/10.1002/1529-0131(200104)44:4<826::AIDANR139>3.0.CO;2-U

[107] Recklies, A.D., Ling, H., White, C. and Bernier, S.M. (2005) Inflammatory cytokines induce production of $\mathrm{CH}_{3} \mathrm{~L} 1$ by articular chondrocytes. The Journal of Biological Chemistry, American Society for Biochemistry and Molecular Biology. 280, 41213-21.

http://dx.doi.org/10.1074/jbc.M510146200

[108] Posey, K.L., Coustry, F., Veerisetty, A.C., Hossain, M., Gattis, D., Booten, S. et al. (2017) Antisense Reduction of Mutant COMP Reduces Growth Plate Chondrocyte Pathology. Molecular Therapy, 25, 705-14. http://dx.doi.org/10.1016/j.ymthe.2016.12.024

[109] Bonneh-Barkay, D., Bissel, S.J., Kofler, J., Starkey, A., Wang, G. and Wiley, C.A. (2012) Astrocyte and macrophage regulation of $Y K L-40$ expression and cellular response in neuroinflammation. Brain Pathology (Zurich, Switzerland), Blackwell Publishing Ltd. 22, 530-46. http://dx.doi.org/10.1111/j.1750-3639.2011.00550.x

[110] Bhardwaj, R., Yester, J.W., Singh, S.K., Biswas, D.D., Surace, M.J., Waters, M.R. et al. (2015) RelB/p50 complexes regulate cytokine-induced YKL-40 expression. The Journal of Immunology, 
194, 2862-70. http://dx.doi.org/10.4049/jimmunol.1400874

[111] Jang, E., Kim, J.-H., Lee, S., Kim, J.-H., Seo, J.-W., Jin, M. et al. (2013) Phenotypic polarization of activated astrocytes: the critical role of lipocalin-2 in the classical inflammatory activation of astrocytes. The Journal of Immunology, American Association of Immunologists. 191, 5204-19. http://dx.doi.org/10.4049/jimmunol.1301637

[112] Kawamura, K., Shibata, T., Saget, O., Peel, D. and Bryant, P.J. (1999) A new family of growth factors produced by the fat body and active on Drosophila imaginal disc cells. Development (Cambridge, England), 126, 211-9.

[113] Irving, P., Ubeda, J.-M., Doucet, D., Troxler, L., Lagueux, M., Zachary, D. et al. (2005) New insights into Drosophila larval haemocyte functions through genome-wide analysis. Cellular Microbiology, Blackwell Science Ltd. 7, 335-50. http://dx.doi.org/10.1111/j.1462-

5822.2004.00462.X 
Table 1: Expression of chitinase-like proteins in different cell types

\begin{tabular}{|c|c|c|c|c|c|}
\hline Cell type & YKL-40 & BRP-39 & Ym1 & IDGF & My-Clp1 \\
\hline Macrophages & $\begin{array}{r}\text { Differentiated } \\
\text { macrophages [96] }\end{array}$ & [97] & [98] & N/A & N/A \\
\hline Neutrophils & [99] & [100] & ?][35] & N/A & N/A \\
\hline Epithelial cells & ?][101] & [97] & [102] & N/A & N/A \\
\hline Dendritic cells & [103] & [104] & [105] & N/A & N/A \\
\hline Chondrocytes & [106] & [107] & [108] & $\mathrm{N} / \mathrm{A}$ & N/A \\
\hline Astrocytes & [109] & [110] & [111] & N/A & N/A \\
\hline Larval Fat Body & N/A & $\mathrm{N} / \mathrm{A}$ & $N / A$ & [112] & ? \\
\hline $\begin{array}{c}\text { Haemocytes } \\
\text { (white blood cell } \\
\text { equivalent) }\end{array}$ & N/A & N/A & N/A & [113] & [19] \\
\hline
\end{tabular}

Table 2: Chitinase-like protein expression/activity during injury and repair 


\begin{tabular}{|c|c|c|c|c|}
\hline CLP & Species & Organ & Expression/role & $\begin{array}{l}\text { Receptor } \\
\text { interaction }\end{array}$ \\
\hline \multirow[t]{4}{*}{ YKL-40 } & Human & Brain & $\begin{array}{l}\text { Increased during brain acute injury and } \\
\text { expression sustained long after injury } \\
\text { onset [66] }\end{array}$ & Unknown \\
\hline & & Kidney & $\begin{array}{l}\text { Increased expression during acute } \\
\text { kidney injury [86-88] }\end{array}$ & Unknown \\
\hline & & Liver & $\begin{array}{l}\text { Increased expression during acute and } \\
\text { chronic liver injury [89] }\end{array}$ & Unknown \\
\hline & & Joint & $\begin{array}{l}\text { Increased expression during joint } \\
\text { trauma }[90,91]\end{array}$ & Unknown \\
\hline \multirow[t]{4}{*}{ BRP-39 } & Mouse & Lung & $\begin{array}{l}\text { Limits lung injury in response to } \\
\text { bacterial infection }[16,60] \\
\text { Protective role during acute injury after } \\
\text { bleomycin treatment [92] } \\
\text { Prevents neonatal lung injury [93] }\end{array}$ & $\begin{array}{l}\text { Anti-inflammatory } \\
\text { effects during } \\
\text { bacterial infection } \\
\text { partly IL-13R } \alpha 2 \\
\text { dependent } \\
\text { Unknown }\end{array}$ \\
\hline & & & & Unknown \\
\hline & & Bone & $\begin{array}{l}\text { BRP-39 Inhibition leads to less tissue } \\
\text { destruction following bacterial } \\
\text { infection [57] }\end{array}$ & Unknown \\
\hline & & Kidney & $\begin{array}{l}\text { Sensor of degree of injury and aids } \\
\text { repair [94] }\end{array}$ & Unknown \\
\hline \multirow[t]{4}{*}{ Ym1 } & Mouse & Skin & $\begin{array}{l}\text { Temproal expression after wounding } \\
{[75,76]}\end{array}$ & Unknown \\
\hline & & Lung & $\begin{array}{l}\text { Innate expression limits parasite } \\
\text { burden at expense of lung injury [10] }\end{array}$ & Unknown \\
\hline & & Brain & $\begin{array}{l}\text { Increased expression after stab wound } \\
\text { [72] }\end{array}$ & Unknown \\
\hline & & Kidney & $\begin{array}{l}\text { Increased expression in mice with } \\
\text { severe acute kidney injury [95] }\end{array}$ & Unknown \\
\hline IDGF2 & Drosophila & $\begin{array}{l}\text { Haemolymph } \\
\text { component }\end{array}$ & $\begin{array}{l}\text { Increased expression induced by injury } \\
\text { [18] }\end{array}$ & Unknown \\
\hline IDGF3 $_{3}$ & Drosophila & $\begin{array}{l}\text { Haemolymph } \\
\text { component }\end{array}$ & $\begin{array}{l}\text { Mutation of Idgf3 results in defective } \\
\text { haemolymph clotting upon nematode } \\
\text { entry and larvae injury [17] }\end{array}$ & Unknown \\
\hline
\end{tabular}


Figure 1: Protein homology between different chitinase-like proteins and chitinases. Protein sequences (UniProt ID) of individual chitinase-like proteins (CLPs) or chitinases were aligned and the percentage identity was estimated using Cluster-Omega. Colour of the square corresponds to degree of homology, red $=100 \%$ identical and yellow $=0 \%$ identity. DmIDGF3, Drosophilia melanogaster Imaginal disc growth factor 3 (IDGF3); DmIDGF2, Drosophilia melanogaster IDGF2; Cg-Clp1, Crassostrea gigas Clp1 protein; mBRP-39, Mus musculus BRP-39 (Chil1); mYm1, Mus musculus Ym1 (Chil3); mYm2, Mus musculus Ym2 (Chil4); hYKL-39, Homo sapiens YKL-39 (CH/3L2); hYKL-40, Homo sapiens YKL-40 (CHI3L1); hAMCase, Homo sapiens Acidic mammalian chitinase AMCase (CHIA); hCHIT1, Homo sapiens Chitotriosidase $\mathrm{CHIT}_{1}$ (CHIT1); mAMCase, Mus musculus Acidic mammalian chitinase AMCase (Chia); mChitı, Mus musculus Chitotriosidase Chit1 (Chit1).

Figure 2: Proposed roles of chitinase-like proteins in the lung. CLPs either keep host-defense and tissue repair balanced during infection or cause unbalance in immune regulation and tissue remodeling contributing to pathology during asthma. In the lung, host-defence responses include innate inflammation to control pathogen growth and alterations of the extracellular matrix to rapidly repair the tissue and infection induced injury. CLPs regulate type 2 and type 17 immune responses and inflammasome activation leading to pathogen killing. Additionally CLPs contribute to the balance of injury and repair by influencing collagen deposition and immune regulation. During chronic inflammatory pathologies, such as asthma, CLPs are secreted in abundance. In such situations CLPs also regulate type 2 and type 17 immune responses, but this inflammation tips the balance of regulation toward tissue remodeling and fibrosis. 


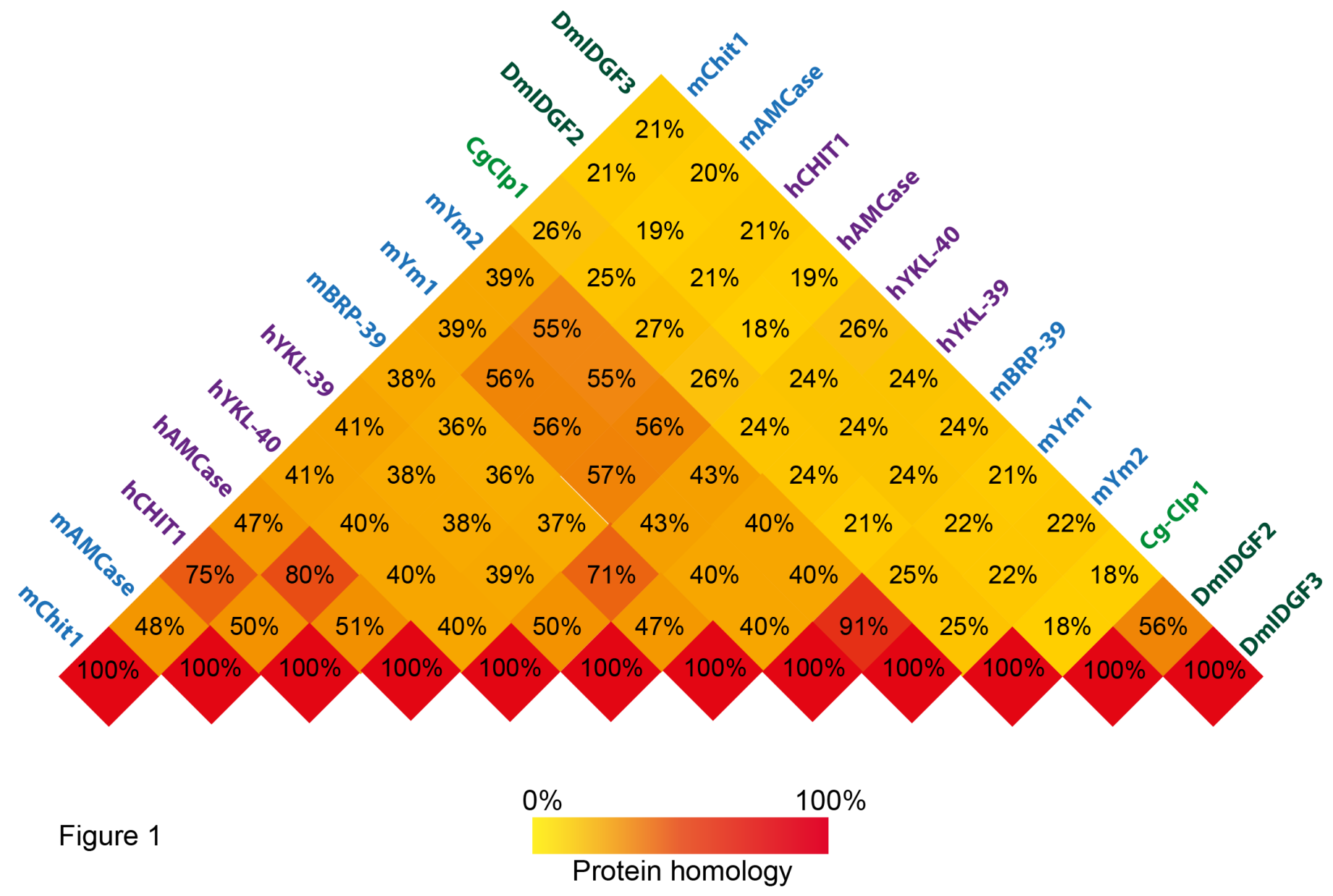




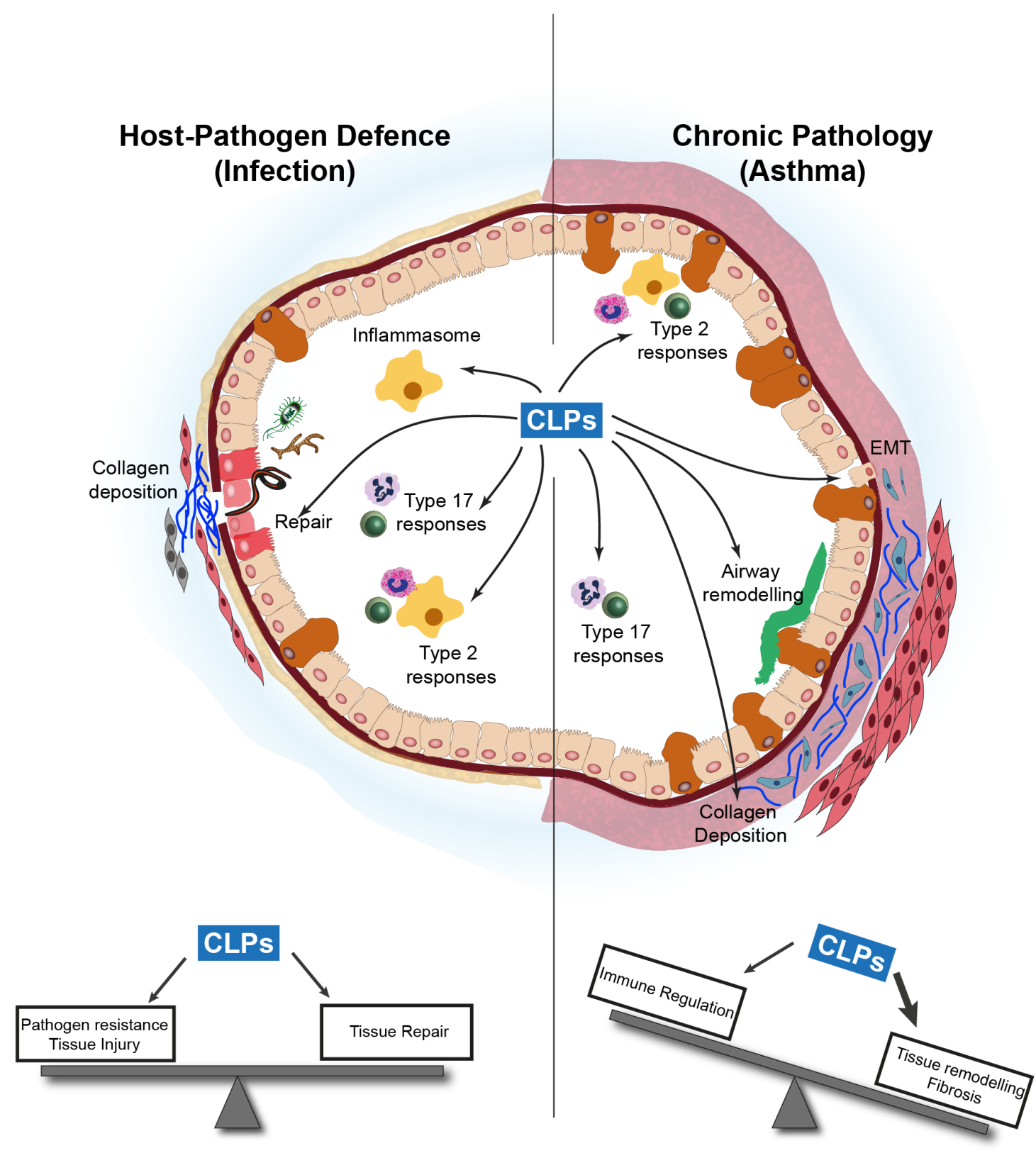

Figure 2 